\title{
Traceability systems and origin based meat products in the South African sheep meat industry
}

\author{
M. van der Merwe and J.F. Kirsten*
}

\begin{abstract}
In a consumer-driven world, consumers want to experience a connection between the product that they are consuming and the product's origin. To guarantee the validity of this connection and therefore the origin attribute of the product, traceability systems are required. The main purpose of this paper is to assess current traceability systems implemented in South African sheep abattoirs, thereby establishing their ability to guarantee the origin of a carcass. Research indicated that the South African sheep abattoirs have traceability systems in place and they can guarantee the origin of a meat product. The descriptive analysis and hypothesis tests identified the tipping factor for the implementation of a traceability system, as the requirement from retail markets to which these abattoirs deliver their product.
\end{abstract}

Keywords: Traceability, South African abattoirs, Karoo Lamb, Fisher's exact test

\section{Introduction}

One of the latest trends in the market for food products is the desire among consumers to know the origin of the food product they purchase and to be physically or 
emotionally connected to the farm and the producer. This consumer need for originbased food is now playing out in a variety of ways as food processors and retailers are labelling their products according to the origin of products. Quite often regional names are used for that identification. In order for the origin and history of a food product to become evident, a transparent supply chain is needed (Trienekens and Beulens, 2011:2). Bulut and Lawrence (2007:1-2) define transparency as production information being publically available at each stage of the production process. However, in order for a supply chain to become transparent traceability systems need to be in place. The official traceability definition according to the EU is "the ability to trace and follow a food, feed, food-producing animal or substance, intended to be or expected to be incorporated into a food or feed, through all stages of production, processing and distribution" (Bulut and Lawrence, 2007:1-2).

Traceability consists of three pillars, namely, the level of the traceability system, the breadth of the traceability system, and the depth of the traceability system. In order to understand the comprehensiveness of the word "traceability", the definitions of level, breadth and depth are discussed in more detail below.

Firstly, the level of a traceability system refers to the way in which a product can be traced back or tracked forward within a supply chain. Three levels exist: genetic, farm to retail and batch traceability. Genetic traceability refers to taking deoxyribonucleic acid (DNA) samples from carcasses to locate the records of the animal. Farm to retail traceability refers to the ability of the system to track the identity of all animals from a farm through the processing and distribution channels to a meat cut. Batch traceability is the traceability from live animals on the farm up to carcasses at the abattoir level without further tracking on the cutting floor - the identities of the source are maintained at the batch level. Secondly, the breadth of a traceability system refers to the amount of information that the traceability system records, for example, the attributes (contact or production information such as free range, organic, Karoo certified and grain fed to name a few) that are recorded for each product. And thirdly, the depth of traceability refers to how far back or forward the traceability system is able to trace or track an item, for example, from the abattoir to the auction, feedlot or sheep farm or from the abattoir to the wholesaler, retailer or butchery (Bulut and Lawrence, 2007:3).

Traceability is therefore a proactive approach to create and maintain a trail of information that follows the path of a product throughout the whole production process to possibly guarantee the origin of a food product. Thereafter the captured information should be made publicly available to upstream and downstream customers in the supply chain to ensure a transparent traceable supply chain.

One iconic South African example of a product with regional identity is Karoo Lamb. The Karoo is the great semi-arid area stretching north-eastwards from the Cape and covers almost $50 \%$ of the total area of South Africa. The area is characterised by flat, dry shrub land on which sheep roam freely. These unique shrubs are furthermore 
what delivers a distinctive flavour to sheep meat from the Karoo region. Typically what comes to mind when thinking about the Karoo are sunsets, windmills, hospitality, free roaming sheep, the smell of earth, freshly brewed coffee and the taste of genuine, fresh from the farm, barbequed under the stars, Karoo lamb chops. All of which contributed to the reasons why the Karoo concept became synonymous with quality tradition and wholesomeness. The diet of the Karoo-reared sheep, in combination with the image and reputation of the Karoo, is what makes the concept of Karoo Lamb most sought after (Kirsten et al., 2008:1).

From the aforementioned it is clear that traceability systems play an integral part in a product with origin as a credence attribute. For the successful certification, branding and marketing of such a product and to be able to guarantee the origin of the product bought by consumers, all members of the specific supply chain should have proper traceability systems in place.

The objective of this article is to assess current traceability systems in the sheep meat industry, specifically the sheep abattoirs, in South Africa and to establish their ability to guarantee the origin of the carcass. This traceability system should be able to protect, manage and govern the food of origin attributes of a meat product in the sheep meat industry. The article develops a detailed description of current traceability systems in the South African sheep meat industry, investigates the decision-making factors impacting on the implementation of a traceability system and identifies the costs and benefits relating to the implementation of a traceability system as identified by participant abattoirs. Five hypotheses were developed and aimed in identifying the tipping factor in the traceability implementation decision-making process at the South African abattoir level.

\section{Methodology}

A random sample of 55 abattoirs from the total population of 284 sheep slaughtering abattoirs listed at the South African Red Meat Abattoir Association (RMAA) was drawn to participate in the study. Many of these abattoirs also slaughter cattle, goats, ostriches and pigs. Of the 55 abattoirs, only 39 were still operational and willing to respond. Figure 1 illustrates the sample representation of the 39 participant abattoirs in South Africa per province. Of the 39 investigated, 11 are located in the Karoo region. 


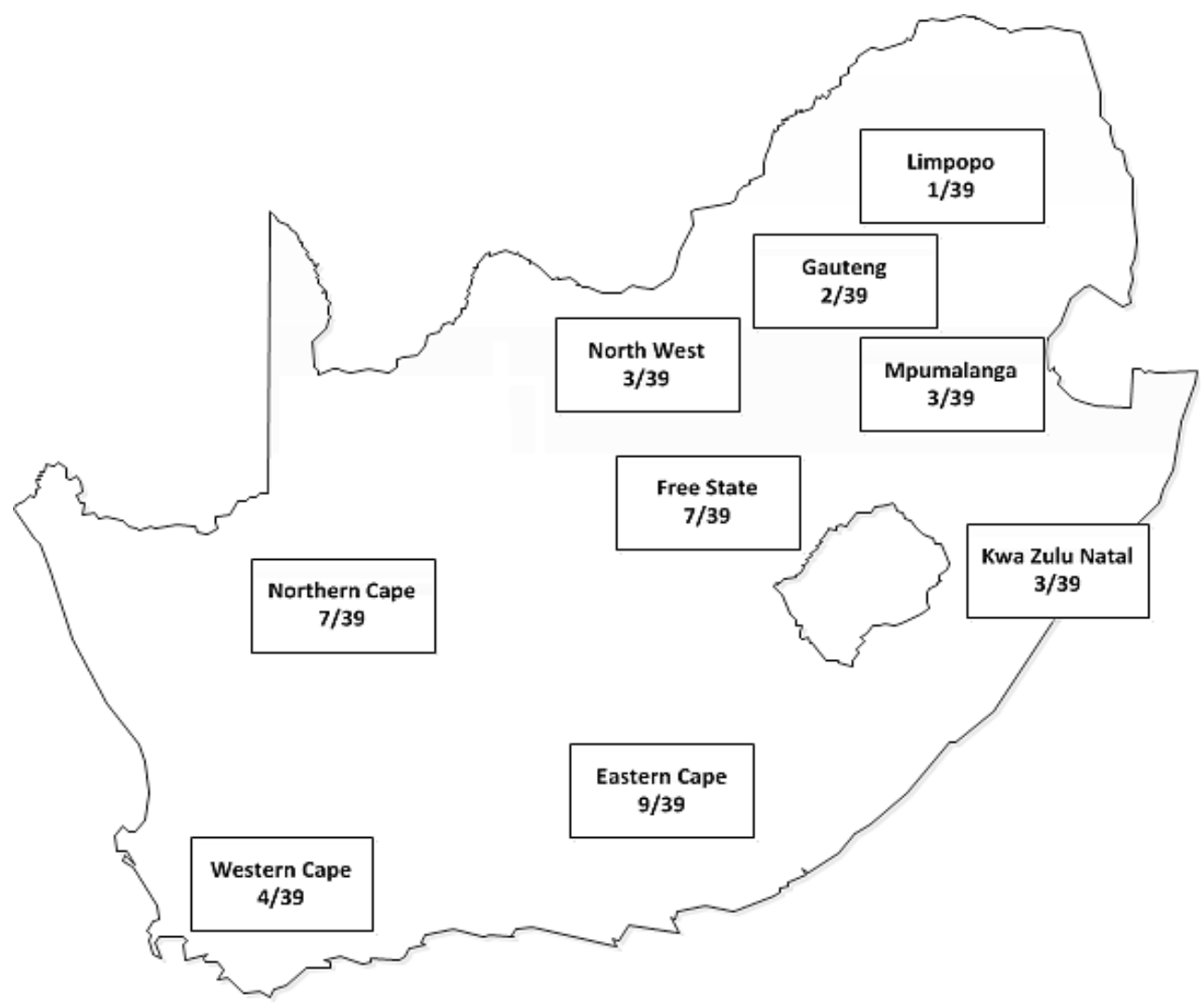

Figure 1: Participant abattoirs per province

Data collection was mainly done by means of interviewer-administered interviews; contacting and visiting the 39 responding abattoirs in 2012 and conducting surveys based on structured questionnaires. The structured questionnaire included closed questions as well as open-ended questions. Additionally, direct observations of the activities and processes in the participant abattoirs and informal discussions were used in an attempt to enrich the primary data collected. The hypothesised independent variables that could possibly impact the implementation decision of traceability systems at the abattoir level are summarised in Table 1. 
Table 1: Independent variables, expectations and hypotheses

\begin{tabular}{|c|c|c|c|c|}
\hline Number & $\begin{array}{l}\text { Independent } \\
\text { Variable }\end{array}$ & $\begin{array}{l}\mathrm{H}_{0}:=1 \\
\text { (Independence) }\end{array}$ & Expectation & $\begin{array}{l}\mathrm{H}_{\mathrm{a}}:>1 \\
\text { (Positive } \\
\text { Association) }\end{array}$ \\
\hline 1 & Size & $\begin{array}{l}\text { The presence } \\
\text { of a traceability } \\
\text { system is } \\
\text { independent of } \\
\text { the size of the } \\
\text { abattoir. }\end{array}$ & $\begin{array}{l}\text { Larger abattoirs } \\
\text { are more likely to } \\
\text { have traceability } \\
\text { systems in place. }\end{array}$ & $\begin{array}{l}\text { The proportion } \\
\text { of abattoirs } \\
\text { with traceability } \\
\text { systems is higher } \\
\text { among large } \\
\text { abattoirs. }\end{array}$ \\
\hline 2 & Capital level & $\begin{array}{l}\text { The presence } \\
\text { of a traceability } \\
\text { system is } \\
\text { independent of } \\
\text { the capital of the } \\
\text { abattoir. }\end{array}$ & $\begin{array}{l}\text { More capital } \\
\text { intensive abattoirs } \\
\text { are more likely to } \\
\text { have traceability } \\
\text { systems in place. }\end{array}$ & $\begin{array}{l}\text { The proportion } \\
\text { of abattoirs } \\
\text { with traceability } \\
\text { systems is higher } \\
\text { among capital } \\
\text { intensive abattoirs. }\end{array}$ \\
\hline 3 & $\begin{array}{l}\text { Market outlet } \\
\text { points }\end{array}$ & $\begin{array}{l}\text { The presence } \\
\text { of a traceability } \\
\text { system is } \\
\text { independent of } \\
\text { the outlet market } \\
\text { of the abattoir. }\end{array}$ & $\begin{array}{l}\text { Abattoirs that } \\
\text { deliver their } \\
\text { product to retailers } \\
\text { are more likely to } \\
\text { have traceability } \\
\text { systems in place. }\end{array}$ & $\begin{array}{l}\text { The proportion } \\
\text { of abattoirs } \\
\text { with traceability } \\
\text { systems is higher } \\
\text { among abattoirs } \\
\text { delivering to } \\
\text { retailers. }\end{array}$ \\
\hline 4 & $\begin{array}{l}\text { Presence of } \\
\text { HAS }\end{array}$ & $\begin{array}{l}\text { The presence } \\
\text { of a traceability } \\
\text { system is } \\
\text { independent of } \\
\text { the presence of } \\
\text { a HAS system at } \\
\text { the abattoir. }\end{array}$ & $\begin{array}{l}\text { Abattoirs that have } \\
\text { HAS systems in } \\
\text { place are more } \\
\text { likely to have a } \\
\text { traceability system } \\
\text { in place. }\end{array}$ & $\begin{array}{l}\text { The proportion } \\
\text { of abattoirs } \\
\text { with traceability } \\
\text { systems is higher } \\
\text { among abattoirs } \\
\text { that have HAS in } \\
\text { place. }\end{array}$ \\
\hline 5 & $\begin{array}{l}\text { Vertical } \\
\text { integration }\end{array}$ & $\begin{array}{l}\text { The presence } \\
\text { of a traceability } \\
\text { system is } \\
\text { independent } \\
\text { of vertical } \\
\text { integration up } \\
\text { and down from } \\
\text { the abattoir. }\end{array}$ & $\begin{array}{l}\text { Abattoirs that } \\
\text { are vertically } \\
\text { integrated up } \\
\text { or down in the } \\
\text { supply chain are } \\
\text { more likely to } \\
\text { have traceability } \\
\text { systems in place. }\end{array}$ & $\begin{array}{l}\text { The proportion } \\
\text { of abattoirs } \\
\text { with traceability } \\
\text { systems is higher } \\
\text { among abattoirs } \\
\text { that are vertically } \\
\text { integrated. }\end{array}$ \\
\hline
\end{tabular}

For survey research, the usual approach to follow for contingency tables is the Chi-square $\left(\chi^{2}\right)$ test statistic, where the Chi-square test is applied to each cell of the contingency table. However, when the sample size is small, the results produced by the Chi-square test statistic may be misleading. In the case of a small, unenlargable sample, the Fisher's exact test is the more accurate to use as it is specifically developed for exact inference on small samples. The null hypothesis of this test is one based on 
independence; the relative proportions of one variable are independent of the second variable. The result of the Fisher's exact test is an exact p-value that can be compared with a specific level of significance, usually at $5 \%$, to determine the independence of the two variables compared in each hypothesis (McDonald, 2009:1-2).

\section{Descriptive overview of the surveyed abattoirs}

South African sheep abattoirs are on average 26 years old, with some being around since 1927. This might be due to the high capital investment (valued at between R750 000 and R110 million) needed to establish a South African abattoir. The high capital outlays of South African abattoirs can be explained by the strict meat hygiene regulations as well as private standards applied by retailers. This inflates capital expenditure of the buildings and the structure surrounding it as well as expensive equipment and cold room facilities, or, in the case of high throughput, the abattoirs' state of the art equipment. When comparing the South African abattoirs with those in Australia and New Zealand, we see capital investments of $\$ 75000$ for a low throughput abattoir and as high as $\$ 75$ million for a state of the art, high throughput abattoir (FAO, 2008). The high capital investment requires these abattoirs to maintain high slaughter volumes per week. The RMAA in South Africa classifies abattoirs into low (slaughtering 12 to 120 sheep per day) and high (slaughtering 121 to 600 or more sheep per day) throughput abattoirs. Due to the fact that many of the abattoirs increased their capacity to well above the 600 unit mark, a very high (more than 600) throughput category, was added during the research (Figure 2).

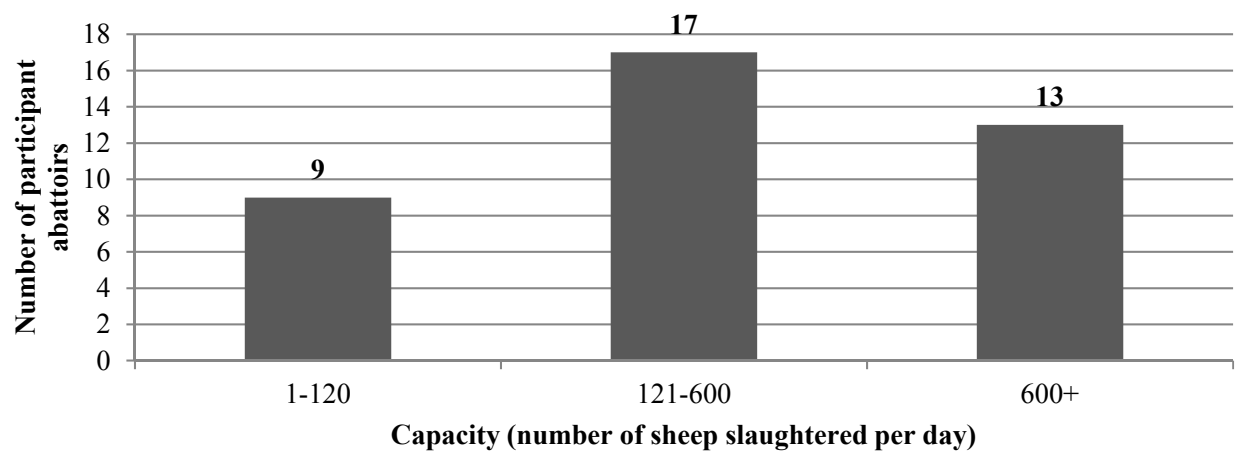

Figure 2: Capacity frequency of abattoirs per category

Of the participant abattoirs, $87 \%$ are privately or independently owned and not group owned by a mother company. Figure 3 indicates the level of vertical integration of 
participant abattoirs. Of the participant abattoirs, $84 \%$ are vertically integrated. In some cases abattoirs owned both a sheep farm or feedlot and butchery.

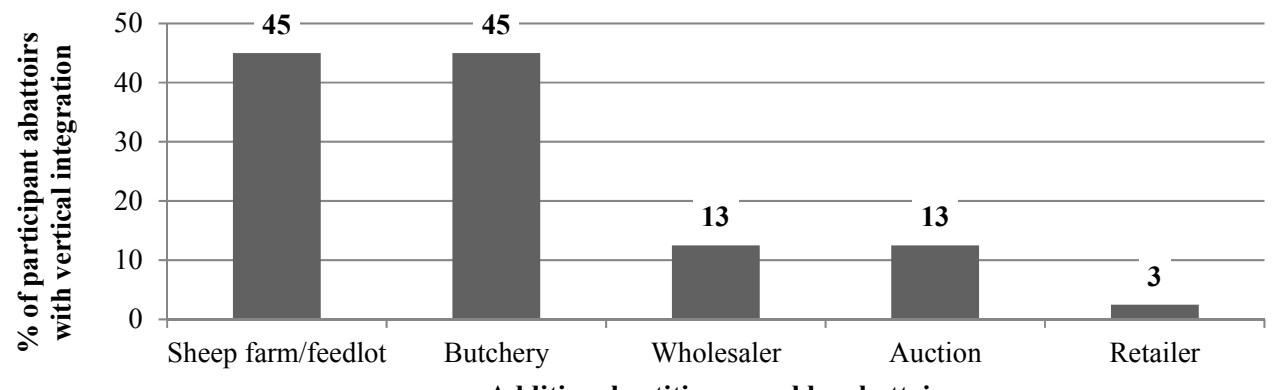

Additional entities owned by abattoir

Figure 3: Level of vertical integration at participant abattoirs

The bulk of carcasses sold by abattoirs are destined for wholesalers (42\%), followed by butcheries (31\%) and retailers (24\%) (Figure 4). Of the participant abattoirs, $8 \%$ provided only a slaughtering service to specifically wholesalers and butcheries. These abattoirs never took ownership of the carcass.

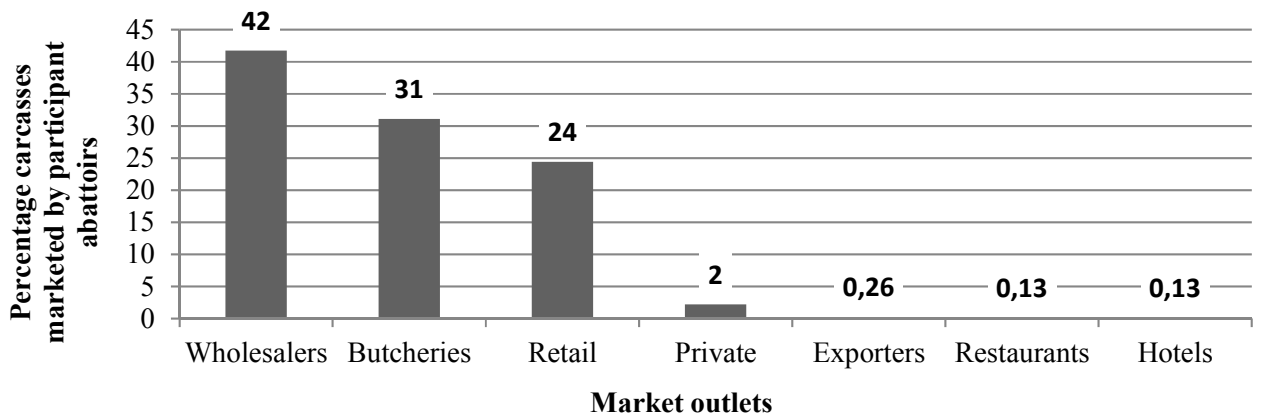

Figure 4: Sheep carcass market off set points

From the data gathered, coded and analysed, the following conclusions can be made in terms of the participant abattoirs' adherence to government regulations:

- $90 \%$ of the abattoirs had Hygiene Assessment Systems (HAS) in place and adhered to government regulations, the majority of these abattoirs were, however, unwilling to disclose the percentage obtained for the HAS audit; and

- $18 \%$ of abattoirs slaughter sheep, which have no form of identification (tattoo's or ear tags). This is a contravention to the Animal Identification Act, 2002 (DAFF, 2008). 
On the other hand, when looking at food safety standards, the following results were found in terms of the abattoirs' uptake of more sophisticated standards:

- $38 \%$ of the abattoirs had Hazard Analysis and Critical Control Points (HACCP) standards in place; and

- $3 \%$ of the abattoirs had the ISO22000 quality management system in place.

\section{An overview of traceability systems implemented by participant abattoirs}

The different types of traceability systems that are in place at the abattoir level, Abaserve, Meat Matrix, Beef Tech, Excel or paper-based systems are illustrated in Figure 5. It came to light that $51 \%$ of the participant abattoirs preferred sophisticated electronic systems (Abaserve, Meat Matrix and Beef Tech), 27\% preferred paperbased systems and 14\% preferred Excel-based systems. It was furthermore noted that high and very high throughput abattoirs are more likely to have sophisticated electronic traceability systems in place. These traceability systems, regardless of the type of system, should be able to protect, manage and govern origin attributes of a meat product. These traceability systems are able to capture at least the following: (i) the name of the owner and the farm or feedlot where the animal was reared, (ii) the number of animals offloaded, the date of offloading, the breed, gender and age of the animals, (iii) the date and time of slaughter, the batch number in which the specific animal was slaughtered, (iv) the live weight, slaughter weight, moisture content, temperature, and $\mathrm{pH}$ of the carcass, (v) the grade and class of the carcass, and (vi) the basic information on the first point of sale such as the selling date and the customer.

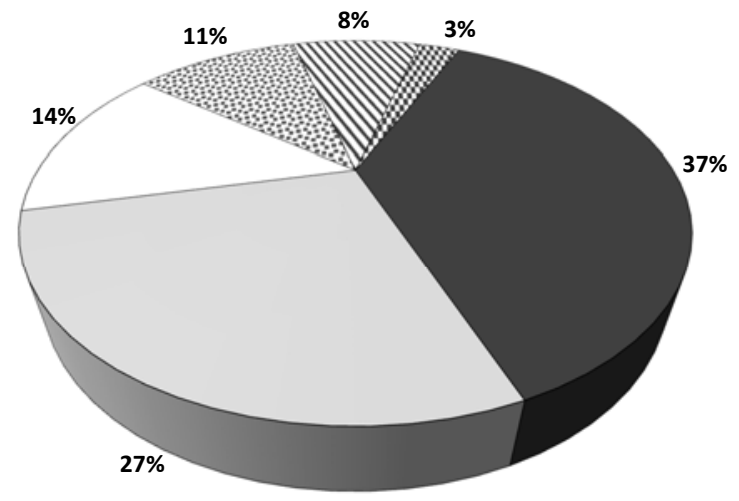

$\square$ Abaserve $\square$ Paper $\square$ Excel M Meat Matrix $\square$ No System $\square$ Beef Tech

Figure 5: Traceability systems at the abattoir level 
A common opinion among the participant abattoirs is that traceability systems are currently mostly used for management purposes, especially the management of inventory, and not so much to guarantee certain quality claims or to ensure food safety. Other reasons for implementing traceability systems are summarised in Table 2.

Table 2: Reasons for having traceability systems in place

\begin{tabular}{|c|c|}
\hline $\begin{array}{l}\text { Reasons for having a traceability } \\
\text { system in place }\end{array}$ & $\begin{array}{l}\text { Reasons for not having a traceability } \\
\text { system in place }\end{array}$ \\
\hline 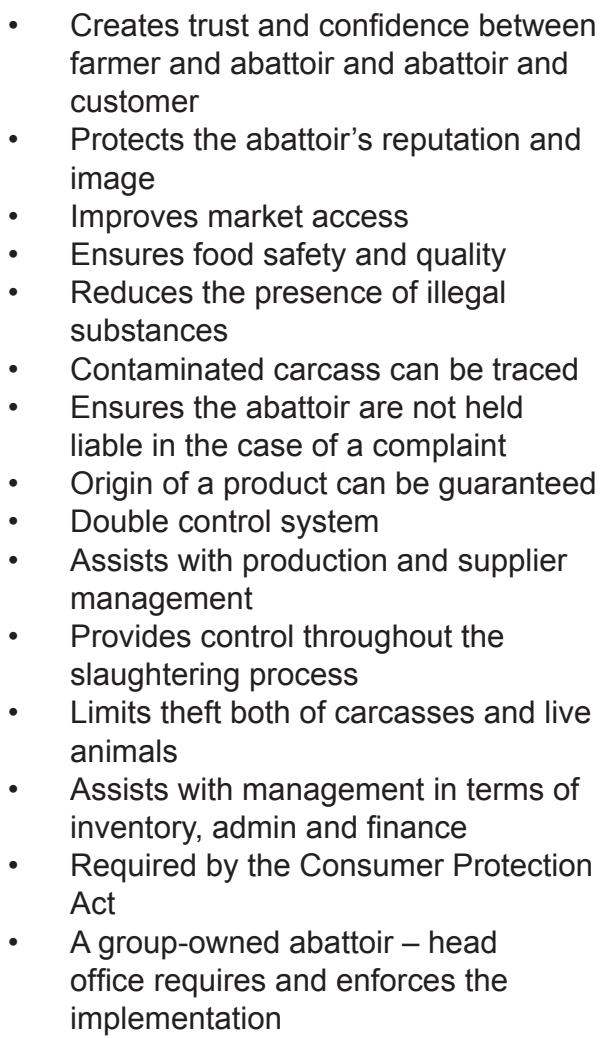 & $\begin{array}{l}\text { - } \quad \text { Expensive to manage it properly } \\
\text { Overhead costs are expensive and a } \\
\text { high capacity is needed to cover this } \\
\text { - } \text { Abattoir might be too small to afford a } \\
\text { system } \\
\text { A traceability system exposes } \\
\text { all irregularities, some abattoir } \\
\text { representatives or owners do not want } \\
\text { it exposed } \\
\text { - Unwillingness to implement the system } \\
\text { and maintain it } \\
\text { Oblivious to the benefits of such a } \\
\text { - } \quad \text { Abstem } \\
\text { impression that it serves no purpose } \\
\text { - Laziness on farmer's side to complete } \\
\text { the forms and abattoir's side to } \\
\text { implement the system } \\
\text { Having a system in place can be time } \\
\text { consuming } \\
\text { Does not want to take responsibility for } \\
\text { the product } \\
\text { It is not demanded by customers } \\
\text { All market players do not insist on it yet } \\
\text { Abattoirs that slaughter only for the } \\
\text { informal sector do not need traceability } \\
\text { systems }\end{array}$ \\
\hline
\end{tabular}

Of the participant abattoirs $82 \%$, was of the opinion that traceability systems will become an inevitable part of the sheep meat industry's future. The key drivers identified for implementation of traceability systems throughout the sheep meat supply chain were:

- Retailers demanding traceability systems to be in place before an abattoir is considered a supplier; 
- Consumers becoming more educated and demanding a system to track and trace food back and forth in supply chains in case of a food safety issue;

- The Consumer Protection Act; and

- The South African government

\section{The economics of traceability systems in meat supply chains}

The owners and/or managers of the participant abattoirs indicated that, given the choice, they will not have traceability systems in place. This is due to the fact that they carry all the costs of the implementation of a traceability system but they gain very few. This section will consequently discuss the economics of traceability systems in the South African sheep meat supply chain.

The majority (97\%) of the participant abattoirs feel that the South African abattoirs are the sole carriers of the cost to implement a traceability system, while $75 \%$ of these participant abattoirs feel that the benefits mostly accrue to the South African consumer. The question; "Why implement traceability systems when all the costs but very few of the benefit befall you?" was then raised. The answer given was that it is a requirement to supply the retail market.

Of the participant abattoirs, only $33 \%$ knew exactly what their annual and/or monthly traceability costs are. It is impossible for these abattoirs to do a proper cost benefit analysis without knowing the costs behind such a system and it is again indicative that there is no pressing reason for the implementation of traceability systems. This furthermore supported the notion that there must be another prevailing reason for the implementation of these traceability systems.

For the $67 \%$ of the surveyed abattoirs that were aware of their costs to implement a traceability system, we could estimate the typical costs for abattoirs of different capacity. A typical abattoir with a slaughtering capacity of 1000 sheep per day could spend approximately R70 000 on start-up fees to implement the Abaserve system. This includes hardware such as scanners and computers as well as the software to get the system in place. Thereafter the Abaserve system requires R5 000 annual licensing fee.

Table 3 summarises the costs and benefits of traceability systems highlighted by the participant abattoirs. 
Table 3: Costs and Benefits of traceability systems

\begin{tabular}{|c|c|}
\hline Costs & Benefits \\
\hline $\begin{array}{l}\text { - Cost of hardware such as computers } \\
\text { and scanners } \\
\text { - Cost of software such as the } \\
\text { Abaserve program } \\
\text { Yearly licensing fees in the case } \\
\text { where a system like Abaserve is used } \\
\text { - Cost of labels and/or tags } \\
\text { Cost of Declaration of health and } \\
\text { livestock removal certificate books } \\
\text { Salary of employees (depending on } \\
\text { the size of the abattoir) to tag the } \\
\text { carcass and to scan or type in the } \\
\text { carcass tag number }\end{array}$ & 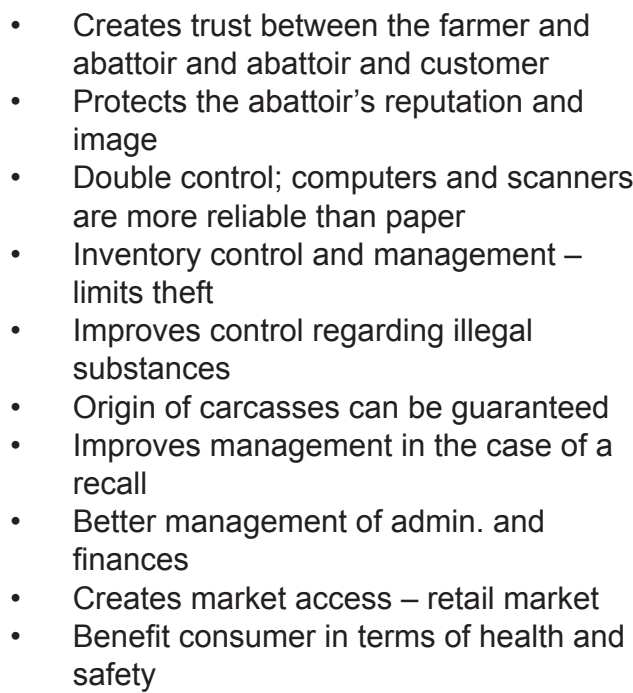 \\
\hline
\end{tabular}

The general feeling among participant abattoirs was that retailers use the requirement of traceability systems as a market entry barrier. The study found that $95 \%$ of the abattoirs that deliver to retailers admitted that they have traceability systems in place purely because it was a requirement to be able to sell their product to retailers. These abattoirs are of the opinion that retailers use the presence of a traceability system as assurance that all other quality and hygiene management systems are in place. This method used by retailers to select supplying abattoirs eliminates all abattoirs that do not have traceability systems in place, even though the abattoirs have quality and hygiene management systems in place. The abattoirs that are eliminated from the retailers' picking lists are usually small abattoirs that are not financially capable and/or do not have the necessary expertise to successfully implement traceability systems.

It was, however, noted that certain retailers, especially those in remote areas where abattoirs are few and far between, do not follow this "unwritten rule" as strictly as the retailers in the more urban areas. This might be as a result of the type of customer that the specific retailer caters for, or it can be because the retailer in the rural area has less bargaining power compared with the retailer in the urban area, and has no alternative other than to buy from the closest abattoir. 


\section{Testing the link between abattoir characteristics and the presence of traceability systems}

For quantitative analysis, the Fisher's exact test was used to test the five hypotheses. A summary of the hypotheses, the results obtained from running the Fisher's exact test in STATA as well as the rejection rules and conclusions are discussed below. Table 4 acts as a summary.

Table 4: Hypotheses test results, rejection rule and conclusion

\begin{tabular}{|c|c|c|c|c|}
\hline Number & Hypotheses & $\begin{array}{l}\text { Fisher's } \\
\text { exact test } \\
\text { (1 sided test) }\end{array}$ & $\begin{array}{l}\text { Rejection rule } \\
(p-\text {-value }>0.05)\end{array}$ & Conclusion \\
\hline 1 & $\begin{array}{l}\text { The proportion } \\
\text { of abattoirs } \\
\text { with traceability } \\
\text { systems is } \\
\text { independent of } \\
\text { abattoir size. }\end{array}$ & 0.556 & $\begin{array}{l}\text { Hypothesis } \\
1 \text { cannot be } \\
\text { rejected on } \\
\text { a } 5 \% \text { level of } \\
\text { confidence. }\end{array}$ & $\begin{array}{l}\text { The size of the abattoir } \\
\text { does not influence } \\
\text { the presence of a } \\
\text { traceability system. }\end{array}$ \\
\hline 2 & $\begin{array}{l}\text { The proportion } \\
\text { of abattoirs } \\
\text { with traceability } \\
\text { systems is } \\
\text { independent } \\
\text { of capital } \\
\text { replacement } \\
\text { value. }\end{array}$ & 0.320 & $\begin{array}{l}\text { Hypothesis } \\
2 \text { cannot be } \\
\text { rejected on } \\
\text { a } 5 \% \text { level of } \\
\text { confidence. }\end{array}$ & $\begin{array}{l}\text { The capital level of } \\
\text { the abattoir does not } \\
\text { influence the presence } \\
\text { of a traceability } \\
\text { system. }\end{array}$ \\
\hline 3 & $\begin{array}{l}\text { The proportion } \\
\text { of abattoirs } \\
\text { with traceability } \\
\text { systems is } \\
\text { independent of } \\
\text { if they deliver to } \\
\text { retailers. }\end{array}$ & 0.0000004 & $\begin{array}{l}\text { Hypothesis } 3 \\
\text { can be rejected } \\
\text { on a } 5 \% \text { level of } \\
\text { confidence. }\end{array}$ & $\begin{array}{l}\text { The fact that abattoirs } \\
\text { deliver to retailers does } \\
\text { influence the presence } \\
\text { of a traceability } \\
\text { system. }\end{array}$ \\
\hline 4 & $\begin{array}{l}\text { The proportion } \\
\text { of abattoirs } \\
\text { with traceability } \\
\text { systems is } \\
\text { independent of } \\
\text { if there is a HAS } \\
\text { system in place. }\end{array}$ & 0.284 & $\begin{array}{l}\text { Hypothesis } \\
4 \text { cannot be } \\
\text { rejected on } \\
\text { a } 5 \% \text { level of } \\
\text { confidence. }\end{array}$ & $\begin{array}{l}\text { The presence of HAS } \\
\text { at the abattoir level } \\
\text { does not influence } \\
\text { the presence of a } \\
\text { traceability system. }\end{array}$ \\
\hline
\end{tabular}




\begin{tabular}{|c|c|c|c|c|}
\hline Number & Hypotheses & $\begin{array}{l}\text { Fisher's } \\
\text { exact test } \\
\text { (1 sided test) }\end{array}$ & $\begin{array}{l}\text { Rejection rule } \\
(p \text {-value }>0.05)\end{array}$ & Conclusion \\
\hline 5 & $\begin{array}{l}\text { The proportion } \\
\text { of abattoirs } \\
\text { with traceability } \\
\text { systems is } \\
\text { independent of } \\
\text { if the abattoir } \\
\text { is vertically } \\
\text { integrated. }\end{array}$ & 0.597 & $\begin{array}{l}\text { Hypothesis } \\
5 \text { cannot be } \\
\text { rejected on } \\
\text { a } 5 \% \text { level of } \\
\text { confidence. }\end{array}$ & $\begin{array}{l}\text { The level of integration } \\
\text { in the supply chain } \\
\text { does not influence } \\
\text { the presence of a } \\
\text { traceability system. }\end{array}$ \\
\hline
\end{tabular}

\subsection{The link between abattoir size and the presence of a traceability system}

Initially it was expected that the size of the abattoir in terms of slaughtering capacity might influence the presence of a traceability system at the abattoir level. The results revealed the opposite. For hypothesis 1, the conclusion was drawn that the size of the abattoir does not affect the presence of a traceability system. A large abattoir that deals with around 3000 animals per day needs a sophisticated traceability system. These systems are usually costly but even though the total variable cost of traceability increases with the size of the abattoir, due to economies of scale, the average fixed cost for the implementation of traceability decreases with an increase in animals slaughtered. A very small abattoir with a capacity of one to two animals per day on the other hand, can easily implement a traceability system without increasing cost. This can be done by means of a paper trail for record keeping where information about the animals entering the abattoir and the information about the carcasses exiting the abattoir are recorded by hand. Therefore both small and large abattoirs have the means to implement traceability systems regardless of their size.

\subsection{The relationship between abattoir capital replacement value and the presence of a traceability system}

It was anticipated that the higher the capital replacement value of the abattoir is, the higher the chance that the particular abattoir will have a traceability system in place. According to the results, this was not the case. For hypothesis 2, the conclusion was drawn that the capital level does not affect the implementation of a traceability system. The capital intensity of an abattoir is linked to the slaughtering capacity the higher the slaughtering capacity, the larger the abattoir and the higher the capital requirement. The conclusion made for hypothesis 1 is therefore also applicable to hypothesis 2 . 


\subsection{The effect of retail market outlets on the presence of a traceability system}

It was initially thought that abattoirs that delivered their product to retailers might influence the presence of a traceability system at the abattoir level, since this acts as a product quality and safety guarantee. This idea was supported by the Fisher's exact test. For hypothesis 3, the conclusion was drawn that abattoirs that slaughter carcasses for the retail market does impact the decision to implement a traceability system. The descriptive statistics act as further confirmation of this statement: $95 \%$ of retail delivering participant abattoirs had traceability systems in place, the other $5 \%$ of abattoirs were abattoirs situated in remote rural areas. Retailers in these areas do not have access to alternative suppliers and meat is therefore bought from these rural abattoirs regardless of the presence of a traceability system. Therefore, for abattoirs to be considered as possible retailer suppliers, especially in more urbanised areas, they need to have proper traceability systems in place.

\subsection{The link between a food safety system at the abattoir level and the presence of a traceability system}

Initially it was expected that abattoirs that have a food safety system (at the minimum a HAS system) in place will also have traceability systems in place. However, the results of the Fisher's exact test indicated otherwise. For hypothesis 4, the conclusion was drawn that the presence of HAS in an abattoir does not impact on the decision of the abattoir to implement a traceability system. The owners and managers of these abattoirs admitted that it was unclear if traceability systems are a requirement of HAS and/or the Meat Safety Act (no. 40 of 2000). Different results on the Fisher's test can therefore be expected if the implementation of traceability systems is indeed a requirement of HAS and/or the Meat Safety Act (no. 40 of 2000) (SAMIC, 2000).

\subsection{The relationship between vertical integration in the sheep meat supply chain and the presence of a traceability system}

It was anticipated that abattoirs that are vertically integrated, either upstream or downstream, would tend to have traceability systems, or better yet, chain-wide traceability systems in place as they own the entire or most of the supply chain operations. This was, however, not the case. For hypothesis 5; the fact that a supply chain is vertically integrated in some way, either by means of a production unit, or a wholesaler or butchery or totally integrated by having all these as part of their supply chain does not affect the presence of a traceability system at the abattoir level. 


\section{Conclusion and recommendation}

In a study done by Bulut and Lawrence (2007), abattoirs and meat processing plants were identified as the weak links when it comes to traceability. Subsequently, it was decided to start the investigation of the presence of traceability systems at the South African sheep abattoir level to get a feel for the readiness of the South African abattoirs to be able to guarantee the origin of a product such as Karoo Lamb.

From the data gathered it was clear that the majority (92\%) of the South African abattoirs have proper traceability systems in place. This makes it possible for these abattoirs to at least distinguish between batches from different farmers and therefore possibly different regions. What is worrying is the fact that very few of the surveyed abattoirs know what the financial implications (costs and benefits) for their business enterprise are when implementing a traceability system. Based on this, a proper cost benefit analysis could not have been done in order to determine the real economic impact on the South African sheep meat industry. Information and perhaps workshops for these abattoirs, to aid them in understanding the costs and benefits as well as the importance of the implementation of a traceability system, are therefore long overdue. Only when these abattoirs are aware of the financial implications, can a proper cost benefit analysis be done.

The fact that $92 \%$ of the participant abattoirs had traceability systems in place, even though they were uncertain about the economic implications of these systems, was interesting. Research showed that only $33 \%$ of abattoirs knew their exact costs and $97 \%$ of abattoirs were certain that they carried all the costs of implementing a traceability system, while $75 \%$ of the participant abattoirs were convinced that all the benefits of a chain wide traceability system fell to the consumer. It just did not make sense from an economic view point. Why would an abattoir carry the cost of implementing a traceability system if most of the benefits fell to the consumer?

The real reason why South African abattoirs had traceability systems in place soon became apparent. Retailers require traceability systems before an abattoir can be considered a supplier to a retailer; the majority (95\%) of retail delivering abattoirs had a traceability system in place. This statement was supported by the Fisher's exact test. This test concluded that hypothesis 3 (the proportion of abattoirs with traceability systems are independent from the market outlet) can be rejected at a 5\% level of significance. This means that the fact that an abattoir delivers to a retailer significantly impacts the decision to implement a traceability system. This furthermore shows the tremendous power that retailers have in the sheep meat supply chain. As for the three $(5 \%)$ retail delivering abattoirs with no traceability systems in place, these were the three abattoirs situated in remote rural areas. Retailers in these regions had little choice other than to buy from these abattoirs as the next best abattoir might be several hundred kilometres away. It also came to light that the lower income clientele they cater for do not require traceability systems. 
At the abattoir level, the traceability systems are quite easily implemented. It is much easier to trace a single carcass in an abattoir than to trace different pieces of one carcass in the processing plant. Therefore, downstream tiers play a vital part in the South African sheep meat industry in terms of traceability and transparency in order to guarantee the origin of a sheep meat product such as Karoo Lamb. Since this study did not include the downstream tiers, meat processors, packers, wholesalers and retailers, it is not possible to conclude that the entire sheep meat supply chain can guarantee a product's origin in the case of a product such as Karoo Lamb. Further research is therefore required to evaluate the other role players in the sheep meat industry for chain-wide traceability systems in order to test the readiness of this chain to guarantee the origin of a product such as Karoo Lamb.

\section{Biographical information}

* Department of Agricultural Economics, Extension and Rural Development, University of Pretoria, Email: melissa.verdermerwe@up.ac.za

\section{Note}

1. The authors would like to thank the Red Meat Development Trust and the Bill and Melinda Gates Foundation for financial assistance, as well as the Red Meat Abattoir Association for their willingness to share the information of their members. The authors would furthermore like to extend their gratitude to all the abattoirs that participated in the survey.

\section{References}

Bulut, H. and Lawrence, J.D. 2007. Meat slaughter and processing plants' traceability levels evidence from Iowa. Proceedings of the NCCC-134 Conference on Applied Commodity Price Analysis, Forecasting and Market Risk Management, Chicago. Available from http:// ageconsearch.umn.edu/bitstream/37576/2/confp20-07.pdf (accessed 14 March 2011).

FAO. 2008. Abattoir development: Options and designs for hygienic basic and medium-sized abattoirs. Available from ftp://ftp.fao.org/docrep/fao/010/ai410e/ai410e00.pdf (accessed 5 December 2014).

Kirsten, J.F., Troskie, D., Vermeulen, H., Schönfeldt, H.C. and Bramley, C. 2008. The potential for Karoo Lamb as origin based meat and a Geographical Indication. Research Report, Department of Agricultural Economics, Extension and Rural Development, University of Pretoria, South Africa.

McDonald, J.H. 2009. Handbook of Biological Statistics, 2nd ed. Sparky House Publishing, Baltimore, Maryland. Test for nominal variables: Fisher's exact test of independence. Available from: http://udel.edu/ mcdonald/statintro.html (accessed 28 August 2012).

South African Department of Agriculture, Forestry and Fisheries. 2008. Identification of animals in terms of the Animal Identification Act (Act. No 6 of 2002). Available from http://www. 
nda.agric.za/vetweb/Animal\%20Identification/Identification\%20of\%20 animals_Feb2008 Web.pdf (accessed 29 May 2012).

South African Meat Industry Company. 2000. Meat Safety Act, No. 40 of 2000. Available from http://www.samic.co.za/forms-a-downloads.html (accessed 31 May 2012).

Trienekens, J.H. and Beulens, A. 2011. Boundaries for transparency in food chains. Proceedings of the System Dynamics and Innovation in Food Networks Forum, IGLS (Austria), 14-17 February 2011. 